\title{
Hot water treatments performed in the base of the broccoli stem reduce postharvest senescence of broccoli (Brassica oleracea L. Var italic) heads stored at $20{ }^{\circ} \mathrm{C}$
}

\author{
Mauro A. Perini ${ }^{\mathrm{a}, 1}$, Ignacio N. Sin ${ }^{\mathrm{a}, 1}$, Andrea M. Reyes Jara ${ }^{\text {a }}$, María E. Gómez Lobato ${ }^{\mathrm{a}}$,

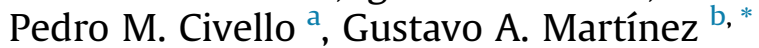

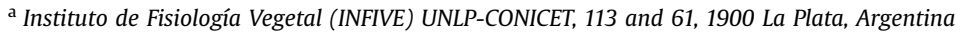 \\ ${ }^{\mathrm{b}}$ Instituto de Investigaciones Biotecnológicas-Instituto Tecnológico de Chascomús (IIB-INTECH) UNSAM-CONICET, Av. Intendente Marino Km 8.5, 7130 \\ Chascomús, Argentina
}

\section{A R T I C L E I N F O}

\section{Article history:}

Received 20 July 2016

Received in revised form

21 November 2016

Accepted 22 November 2016

Available online 23 November 2016

\section{Keywords:}

Broccoli

Heat treatment

Postharvest

Senescence

Physical treatment

\begin{abstract}
A B S T R A C T
Heat treatments cause a moderate and reversible stress that interrupts the normal metabolism (senescence or fruit ripening) of the product. Although there is a large number of reports about heat treatments on broccoli heads, the effect of subjecting only the stems to thermal treatments has not been studied yet. One of the main reasons to analyze this approach is that the hormone ethylene is actively produced in the stem cutting area.

Different hot water treatments were performed on the first $5 \mathrm{~cm}$ of broccoli stems with various combinations of time-temperature. Treatment carried out at $50{ }^{\circ} \mathrm{C}$ for $3 \mathrm{~min}$ was chosen for further analysis of different quality and senescence parameters, taking into account that broccoli heads presented a delayed change in Hue and $\mathrm{L}$ values when compared with controls during storage. While control heads looked yellow, heat-treated samples retained most of their green colour. Furthermore, control heads presented higher weight loss, lower total and soluble protein, and lower total soluble sugar after 3 or 5 storage days, giving evidence of the fact that a heat treatment just on the stem contributes to the delay of broccoli senescence and to the maintenance of the overall quality of the product during storage.
\end{abstract}

(๑) 2016 Elsevier Ltd. All rights reserved.

\section{Introduction}

Broccoli (Brassica oleracea L. Italica group) is a worldwide used vegetable with high nutritional value and health benefits. Broccoli inflorescences are harvested while the floral heads, branchlets and florets are totally immature. Such harvesting causes an important stress and a depletion of water and hormones, which leads to rapid senescence (King and Morris, 1994). During the postharvest period, inflorescences lose their green colour, turn yellow and decrease their nutritional and nutraceutical quality, diminishing the concentration of proteins, sugars, ascorbic acid and glucosinolates (Jia et al., 2009; Page, Griffiths, \& Buchanan-Wollaston, 2001). Diverse methodologies have then been utilized in order to extend the postharvest life of broccoli, including refrigeration (Gillies \&

\footnotetext{
* Corresponding author.

E-mail address: gmartinez@intech.gov.ar (G.A. Martínez).

1 Both authors contributed equally to this work.
}

Toivonen, 1995), modified atmosphere (Eason et al., 2007; Fernández-León, Fernández-León, Lozano, Ayuso, \& GonzálezGómez, 2013), UV-C and UV-B (Aiamla-or, Kaewsuksaeng, Shigyo, \& Yamauchi, 2010; Costa, Vicente, Civello, Chaves, \& Martínez, 2006), 1-MCP (Gong \& Mattheis, 2003; Gómez-Lobato, Hasperué, Civello, Chaves, \& Martínez, 2012; Ma et al., 2010), and heat treatments (Costa, Civello, Chaves, \& Martínez, 2005).

The use of heat treatments as a methodology to extend postharvest life of different products has been studied and their beneficial effects have been well documented (Lu, Vigneault', Charles, \& Raghavan, 2007). Heat treatments cause a moderate and reversible stress that interrupts the normal metabolism (senescence or fruit ripening) of the product (Lu, Vigneault, Charles, \& Raghavan, 2007). As that is a momentary stress, after certain time the product continues with its regular metabolism. Postharvest heat treatments can control insect pests, prevent fungal rots and affect the ripening and senescence of fruits and vegetables (Lurie, Jemric, Weksler, Akiva, \& Gazit, 2004; Porat, Pavoncello, Peretz, Ben-Yehoshua, \& Lurie, 2000). In the cases of ripening and senescence, heat 
treatments induce a momentary stress that reduces the expression of genes related to these processes, which in turn delays the normal ripening and senescence (Büchert, Civello, \& Martínez, 2011; Gómez-Lobato et al., 2012; Martínez \& Civello, 2008).

In broccoli, it was largely documented that both hot water (Tian, Woolf, Bowen, \& Ferguson, 1996) and hot air (Costa et al., 2005; Funamoto, Yamauchi, Shigenaga, \& Shigyo, 2002) treatments can effectively delay postharvest senescence.

Broccoli senescence is accelerated by the gaseous hormone ethylene. It has been shown that treatments with exogenous ethylene or ethephon (an ethylene releasing agent) can accelerate degreening and promote protein degradation and loss of sugars (Gapper et al., 2005). Endogenous ethylene biosynthesis is triggered by harvesting. Surprisingly, Kato et al. (2002) demonstrated that ACC (1-aminocyclopropane-1-carboxylic acid) synthase (ACS), one of the main enzymes involved in ethylene biosynthesis, is mainly induced in the cut surface of stem tissue, in the first $2 \mathrm{~mm}$ thick and the basal portions of curds soon after harvesting.

In this work we performed a heat treatment with hot water in the first $5 \mathrm{~cm}$ of the cut zone of the stem and analyzed several senescence and quality parameters of broccoli heads during postharvest storage.

\section{Materials and methods}

\subsection{Plant material}

Broccoli (Brassica oleracea var. Italica) heads were obtained from a commercial grower in La Plata, Argentina ( $34^{\circ} 59^{\prime} \mathrm{S}$ and $58^{\circ} 3^{\prime} \mathrm{W}$ ) during the spring season of the southern hemisphere. Broccoli heads, healthy and of marketable size, were harvested at 8 a.m. and immediately transported to the laboratory to be processed.

\subsection{Hot water treatments}

Broccoli stems ( $5 \mathrm{~cm}$, approximately) were carefully immersed, so as not to immerse their heads, in $25 \mathrm{~L}$ water baths with a temperature controller and a water circulation system. Six different hot water treatments were performed $\left(3 \mathrm{~min}\right.$ at $20^{\circ} \mathrm{C} ; 5 \mathrm{~min}$ at $47^{\circ} \mathrm{C} ; 3$ and $5 \mathrm{~min}$ at $50{ }^{\circ} \mathrm{C} ; 3$ and $5 \mathrm{~min}$ at $53{ }^{\circ} \mathrm{C}$ ) and nine heads per treatment were used. The treatment for $3 \mathrm{~min}$ at $20{ }^{\circ} \mathrm{C}$ was considered as control. Immediately after the treatments, stems were dried with domestic blotting paper and group heads were processed and labelled as day 0 . The remaining broccoli heads were placed in plastic trays, wrapped with perforated PVC and stored at $20{ }^{\circ} \mathrm{C}$ in darkness. At initials, and after 3 and 5 days of storage, samples were segmented and the inflorescences were frozen using liquid nitrogen and stored at $-20{ }^{\circ} \mathrm{C}$ until their use.

\subsection{Superficial colour}

Superficial colour of broccoli heads was evaluated with a chromameter (CR300, Minolta, Osaka, Japan), measuring the parameters $\mathrm{L}^{*}, \mathrm{a}^{*}$ and $\mathrm{b}^{*}$, and calculating the Hue angle $\left(\mathrm{HUE}^{\circ}\right)$ using the following formulas: $\mathrm{HUE}^{\circ}=\tan ^{-1}(\mathrm{~b} / \mathrm{a})$ when $\mathrm{a}>0$ and $\mathrm{b}>0$; $\mathrm{HUE}^{\circ}=180^{\circ}+\tan ^{-1}(\mathrm{~b} / \mathrm{a})$ when $\mathrm{a}<0$ and $\mathrm{b}>0$. Five heads were used per treatment condition and five measurements were performed on each assayed head.

\subsection{Weight loss}

Broccoli head initial weight was recorded immediately after harvesting. The same heads were then weighted 3 and 5 days after the treatment. Weight loss was evaluated as the percentage of the initial weight and labelled as weight loss (\%). Five heads per treatment were assayed.

\subsection{Determination of chlorophyll content}

Frozen broccoli florets were ground in liquid nitrogen, and $0.1 \mathrm{~g}$ of the resulting powder was mixed with $1 \mathrm{~mL}$ of acetone and stored for $4 \mathrm{~h}$ in darkness. The suspension was centrifuged at $10,000 \times \mathrm{g}$ for $10 \mathrm{~min}$ at $4{ }^{\circ} \mathrm{C}$. The chlorophyll a, chlorophyll b and xanthophylls and carotenes content in the supernatant were measured by spectrophotometry according to Lichtenthaler (1987). All measurements were performed in quintuplicate and expressed as grams of chlorophyll a, chlorophyll b, xanthophylls and carotenes per $\mathrm{kg}$ of fresh tissue.

\subsection{Reducing and total sugars content}

Frozen broccoli florets were ground in liquid nitrogen, and $1 \mathrm{~g}$ of the resulting powder was suspended in $6 \mathrm{~mL}$ of ethanol. The mixture was centrifuged at $10,000 \times \mathrm{g}$ for $10 \mathrm{~min}$ at $4{ }^{\circ} \mathrm{C}$ and $1 \mathrm{~mL}$ of the supernatant was diluted to $5 \mathrm{~mL}$ using distilled water. This extract was utilized to determine the content of reducing sugars by using the Somogyi-Nelson method (Southgate, 1977).

For total sugar determination, $0.1 \mathrm{~mL}$ of the same ethanol extract was mixed with $1 \mathrm{~mL}$ of $2 \mathrm{~g} \mathrm{~L}^{-1}$ anthrone at $66 \% \mathrm{w} / \mathrm{w} \mathrm{H}_{2} \mathrm{SO}_{4}$. The mixture was incubated at $100{ }^{\circ} \mathrm{C}$ for $12 \mathrm{~min}$, cooled in ice-water bath per 20 min in darkness and the sugar content was measured spectrophotometrically at $625 \mathrm{~nm}$.

Measurements were performed in triplicate and results were expressed as g glucose per $\mathrm{kg}$ fresh tissue.

\subsection{Total and soluble protein content}

For soluble protein content measurement, frozen broccoli florets were ground in liquid nitrogen and $0.5 \mathrm{~g}$ of the resulting powder was mixed with $5 \mathrm{~mL}$ of a buffer solution [50 mM Tris- $\mathrm{HCl}$, $0.4 \quad \mathrm{~mL} \mathrm{~L}^{-1} \quad \beta$-mercaptoethanol and $2 \mathrm{mM}$ ethylenediaminetetraacetic acid, $\mathrm{pH}$ 7.5]. The mixture was centrifuged at $10,000 \times \mathrm{g}$ for $10 \mathrm{~min}$ at $4{ }^{\circ} \mathrm{C}$ and the soluble protein content was determined in the supernatant, according to Bradford (1976), using bovine serum albumin (Sigma, St Louis, MO, USA) as standard.

For total protein content measurement, $0.3 \mathrm{~g}$ of frozen broccoli powder was homogenized with $10 \mathrm{~mL}$ of extraction buffer [0.1 mM $\mathrm{NaOH}$ and $10 \mathrm{~g} \mathrm{~L}^{-1}$ sodium dodecyl sulfate (SDS)] and heated at $100{ }^{\circ} \mathrm{C}$ for $10 \mathrm{~min}$. Samples were centrifuged at $10,000 \times \mathrm{g}$ for $20 \mathrm{~min}$ at $4{ }^{\circ} \mathrm{C}$. In order to precipitate proteins, $5 \mathrm{vol}$ of acetone were added to the supernatant, which was then incubated at $-20^{\circ} \mathrm{C}$ for $12 \mathrm{~h}$ and centrifuged at $13,000 \times \mathrm{g}$ for $10 \mathrm{~min}$ at $4{ }^{\circ} \mathrm{C}$. The obtained precipitate was dissolved in $0.2 \mathrm{~mL}$ of $0.1 \mathrm{mM} \mathrm{NaOH}$ and $10 \mathrm{~g} \mathrm{~L}^{-1}$ SDS and the protein content was measured according to Lowry, Rosebrough, Lewis Farr, and Randall (1951) using bovine serum albumin as standard. All measurements were performed in triplicate and soluble as well as total protein content was expressed as gram per $\mathrm{kg}$ of fresh tissue.

\subsection{Total phenolic compounds}

Frozen broccoli florets were ground in liquid nitrogen and $1 \mathrm{~g}$ of the resulting powder was suspended in $6 \mathrm{~mL}$ of ethanol. The mixture was centrifuged at $9000 \times \mathrm{g}$ for $10 \mathrm{~min}$ at $4{ }^{\circ} \mathrm{C}$ and the supernatant was used to determine total phenolic compounds according to Zieslin and Ben-Zaken (1992). A $50 \mu \mathrm{L}$ aliquot of the extract was added to $500 \mathrm{~mL}$ of water and $100 \mu \mathrm{L}$ of $0.5 \mathrm{mM}$ Folin-Ciocalteu reagent. After 3 min of incubation at $25^{\circ} \mathrm{C}, 500 \mu \mathrm{L}$ of $10 \% \mathrm{w} / \mathrm{v} \mathrm{Na}_{2} \mathrm{CO}_{3}$ solution was added and the reaction mixture was incubated for $1 \mathrm{~h}$ in darkness at the same temperature. The 
samples were centrifuged at $4500 \times \mathrm{g}$ for $10 \mathrm{~min}$ and the absorbance was measured at $760 \mathrm{~nm}$. The total phenolic content was calculated using gallic acid as standard. Measurements were performed in triplicate and results were expressed as mg galic acid per $\mathrm{kg}$ of fresh tissue.

\subsection{Statistical analysis}

Data for surface colour, Hue angle value and $\mathrm{L}$ value, were analyzed by ANOVA and the means were compared by Tukey test ( $p<0.05$ ). Data for chlorophyll a, chlorophyll b, xanthophylls and carotenes, soluble and reducing sugars, total protein, soluble protein, total phenolic and weight loss compounds were analyzed by ANOVA and the means were compared by Dunnett test with two tails $(\mathrm{p}<0.05)$.

\section{Results}

\subsection{Heat treatment selection}

The first $5 \mathrm{~cm}$ of broccoli stems were immersed in hot water at different combinations of time-temperature. Then, samples were stored for five days at $20^{\circ} \mathrm{C}$ in order to accelerate senescence.

Hue values varied from 139.8 to 144.6 at initial time with no difference among treatments, and decreased in all samples during storage at $20^{\circ} \mathrm{C}$ (Table 1 ). In non-treated heads, Hue decreased to until 108 after three days and then reached values near to 87, indicating an intense yellowing. Treatment at $47{ }^{\circ} \mathrm{C}$ for $3 \mathrm{~min}$ caused a lower decrement of Hue value after three days but not after five days. Treatments at $50{ }^{\circ} \mathrm{C}$ reduced the yellowing, particularly after three days. Also, the reduction of Hue values was

Table 1

Changes in Hue values of broccoli heads during storage at $20^{\circ} \mathrm{C}$.

\begin{tabular}{|c|c|c|c|c|}
\hline Treatments & & Day $0^{*}$ & Day $3^{*}$ & Day $5^{*}$ \\
\hline $20{ }^{\circ} \mathrm{C}$ & $3 \mathrm{~min}$ & $139.8 \pm 1.4^{\mathrm{a}}$ & $108.4 \pm 2.3^{\mathrm{a}}$ & $86.9 \pm 0.9^{a}$ \\
\hline $47^{\circ} \mathrm{C}$ & $5 \mathrm{~min}$ & $144.3 \pm 1.6^{\mathrm{a}}$ & $120.8 \pm 2.1^{b . c}$ & $95.1 \pm 1.3^{a . b}$ \\
\hline \multirow[t]{2}{*}{$50{ }^{\circ} \mathrm{C}$} & $3 \mathrm{~min}$ & $143.6 \pm 3.5^{\mathrm{a}}$ & $133.5 \pm 1.3^{\mathrm{d}}$ & $108.2 \pm 5.6^{\text {b.c }}$ \\
\hline & $5 \mathrm{~min}$ & $139.4 \pm 1.1^{\mathrm{a}}$ & $135.4 \pm 2.0^{\mathrm{d}}$ & $115.3 \pm 6.3^{c}$ \\
\hline \multirow[t]{2}{*}{$53^{\circ} \mathrm{C}$} & $3 \mathrm{~min}$ & $144.6 \pm 1.5^{\mathrm{a}}$ & $128.0 \pm 1.9^{c . d}$ & $99.4 \pm 3.0^{\mathrm{a} . \mathrm{b}}$ \\
\hline & $5 \mathrm{~min}$ & $140.7 \pm 1.1^{\mathrm{a}}$ & $119.3 \pm 2.2^{\mathrm{b}}$ & $88.7 \pm 1.4^{\mathrm{a}}$ \\
\hline
\end{tabular}

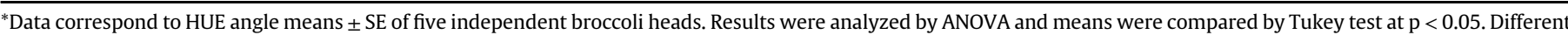
letters indicate significant statistical differences between treatments at the same storage time.

Table 2

Changes in ${ }^{*} \mathrm{~L}$ values of broccoli heads during storage at $20^{\circ} \mathrm{C}$.

\begin{tabular}{|c|c|c|c|c|}
\hline Treatments & & Day $0^{*}$ & Day $3^{*}$ & Day $5^{*}$ \\
\hline $20^{\circ} \mathrm{C}$ & $3 \mathrm{~min}$ & $37.7 \pm 0.3^{\mathrm{a}}$ & $47.5 \pm 0.5^{\mathrm{d}}$ & $54.9 \pm 1.6^{\mathrm{a}}$ \\
\hline $47^{\circ} \mathrm{C}$ & $5 \mathrm{~min}$ & $38.9 \pm 0.3^{\mathrm{a}}$ & $45.0 \pm 0.4^{\mathrm{a} . \mathrm{c}}$ & $53.2 \pm 0.8^{a . b}$ \\
\hline \multirow[t]{2}{*}{$50^{\circ} \mathrm{C}$} & $3 \mathrm{~min}$ & $38.6 \pm 0.3^{\mathrm{a}}$ & $43.1 \pm 0.4^{\mathrm{b} . \mathrm{c}}$ & $50.9 \pm 0.9^{a . b}$ \\
\hline & $5 \mathrm{~min}$ & $38.8 \pm 0.4^{\mathrm{a}}$ & $42.2 \pm 0.4^{\mathrm{b}}$ & $49.2 \pm 1.0^{\mathrm{b}}$ \\
\hline \multirow[t]{2}{*}{$53^{\circ} \mathrm{C}$} & $3 \mathrm{~min}$ & $38.0 \pm 1.2^{\mathrm{a}}$ & $45.2 \pm 0.5^{\mathrm{a}}$ & $53.2 \pm 0.6^{\text {a.b }}$ \\
\hline & $5 \mathrm{~min}$ & $39.3 \pm 0.4^{\mathrm{a}}$ & $46.2 \pm 0.5^{\mathrm{a} . \mathrm{d}}$ & $54.6 \pm 0.9^{\mathrm{a}}$ \\
\hline
\end{tabular}

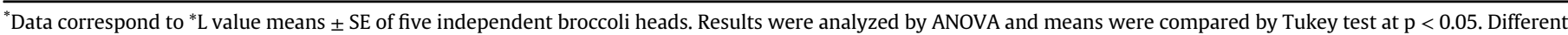
letters indicate significant statistical differences between treatments at the same storage time.

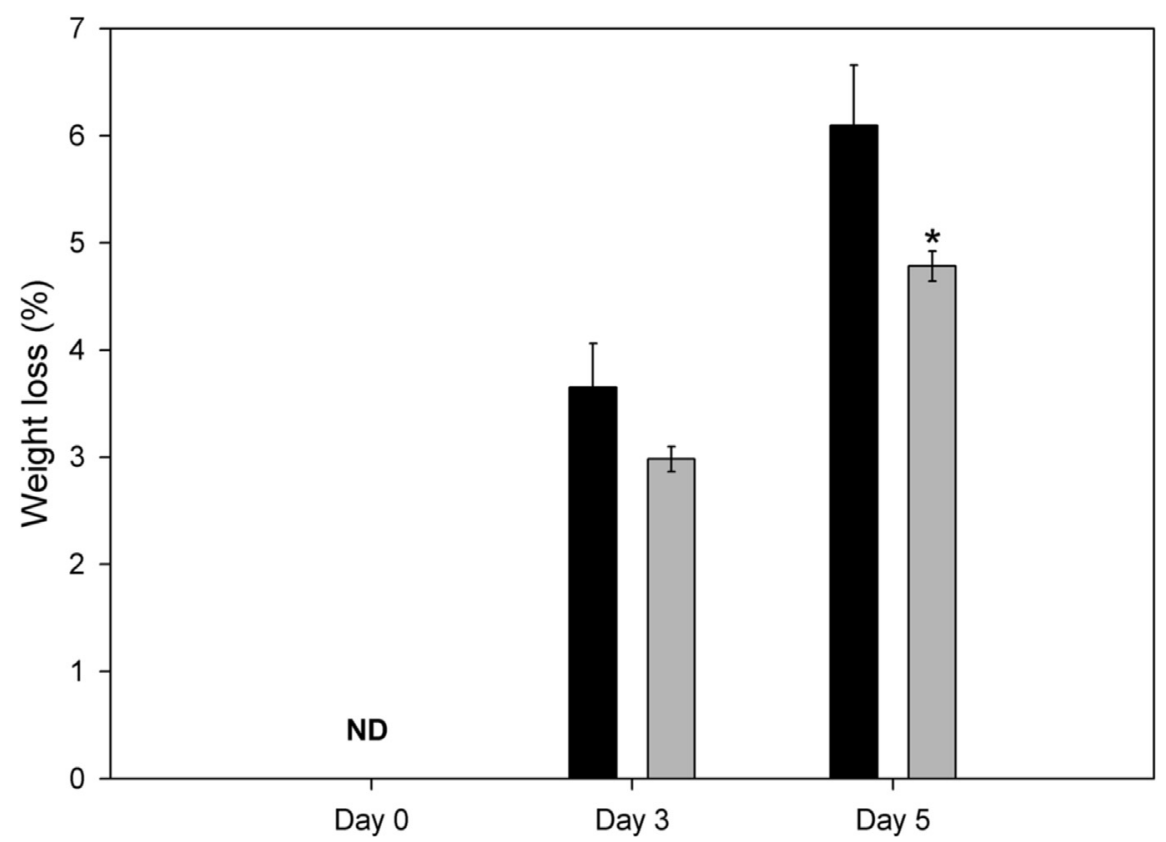

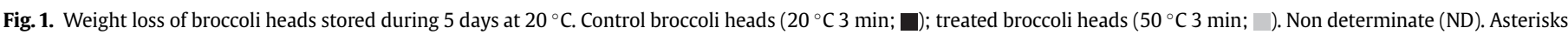
indicate significant statistical differences at the same storage time between control $\left(20^{\circ} \mathrm{C}\right)$ and treated $\left(50{ }^{\circ} \mathrm{C}\right)$ samples. 
significantly lower than controls after five days. Finally, samples treated at $53{ }^{\circ} \mathrm{C}$ showed a lower reduction of Hue values in comparison to controls after three days, but these differences did not remain after five days.

L values ranged from 37.7 to 39.3 at the beginning of the assay and increased during storage at $20^{\circ} \mathrm{C}$, indicating an increase in colour brightness, due to the characteristic change from dark green to yellow during senescence of broccoli heads. The highest increments were detected in the control and the $53{ }^{\circ} \mathrm{C}$ treated samples, while the lowest $\mathrm{L}$ values were those of samples treated at $50{ }^{\circ} \mathrm{C}$ (Table 2)

Based on results obtained with Hue and $\mathrm{L}$ values, treatment performed at $50{ }^{\circ} \mathrm{C}$ during 3 min was chosen for further analysis of different quality and senescence parameters.

\subsection{Weight loss}

Immediately after treatments, heated samples did not show weight loss. During storage at $20^{\circ} \mathrm{C}$, an average weight loss of $3-4 \%$ was measured after three days with no difference between control and treated samples. However, the weight loss was higher in controls (6.0\%) when compared with heated samples (4.8\%) after five days (Fig. 1).

\subsection{Chlorophyll content}

The content of chlorophylls $a$ and $b$ decreased during storage at $20{ }^{\circ} \mathrm{C}$. Control samples showed a rapid decline in chlorophylls, losing more than $60 \%$ of the initial content after three days of storage. In contrast, heat treated samples presented higher levels of chlorophylls, losing only $22 \%$ of the chlorophyll $a$ and $40 \%$ of the chlorophyll $b$ at the same storage period (Fig. 2). Levels of chlorophylls were similar in both control and heated samples after five days. Delaying of chlorophyll degradation correlated with a similar delay in Hue an L changes after three days of storage, when control heads looked yellow, while heat-treated samples retained most of

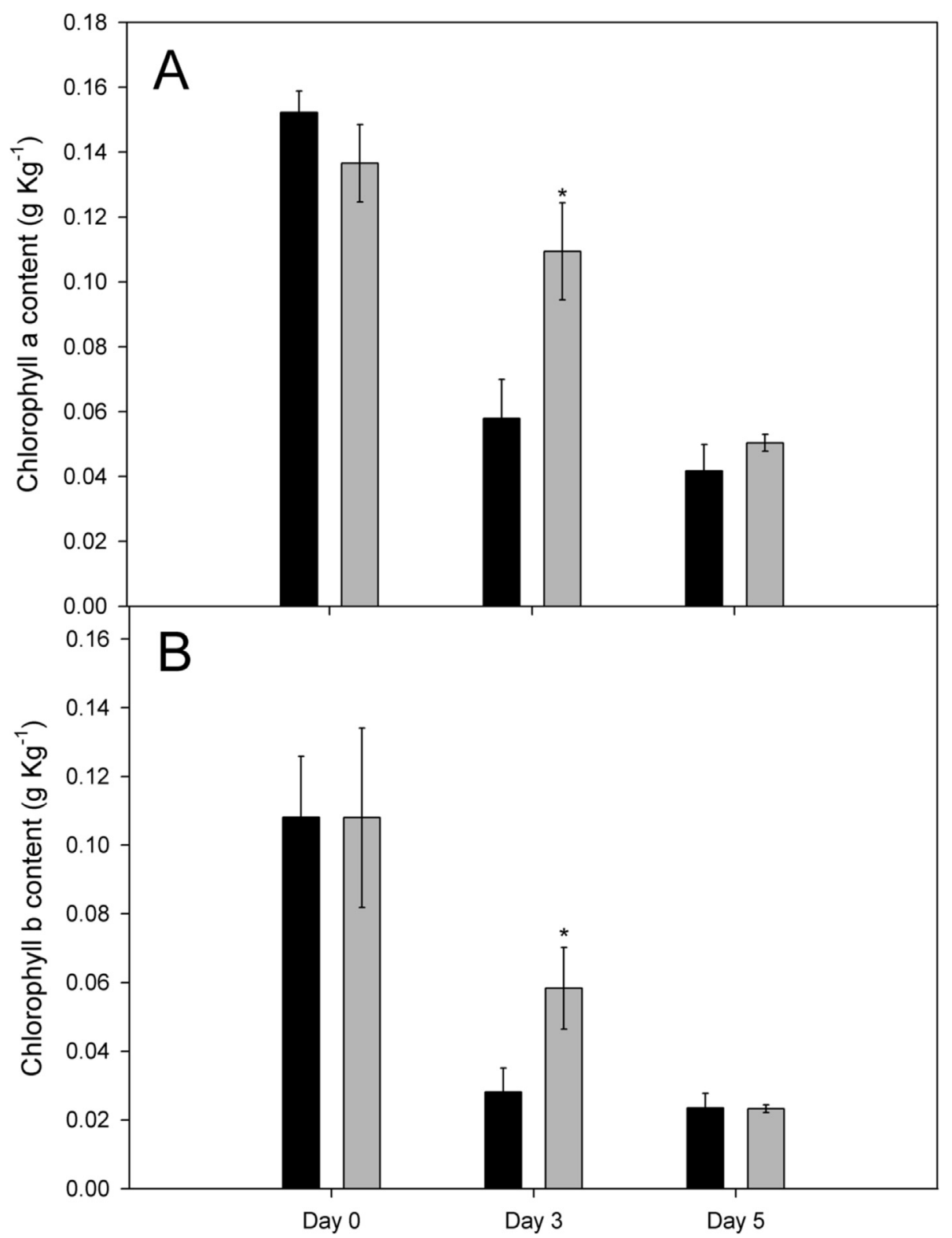

Fig. 2. Changes in chlorophyll a (A) and chlorophyll b (B) content of broccoli heads stored during 5 days at $20{ }^{\circ} \mathrm{C}$. Control broccoli heads (20 ${ }^{\circ} \mathrm{C} 3$ min; $\left(50{ }^{\circ} \mathrm{C} 3 \mathrm{~min} ; \quad\right)$. Asterisks indicate significant statistical differences at the same storage time between control $\left(20^{\circ} \mathrm{C}\right)$ and treated $\left(50{ }^{\circ} \mathrm{C}\right)$ samples. 
their green colour.

\subsection{Carotenoids and xanthophylls content}

The content of carotenoids and xantophylls increased almost $60 \%$ in control samples after five days of postharvest storage (Fig. 3a). Differently, heat treated samples did not change the level of carotenoids and xanthophylls through the same period. When the content of carotenoids and xanthophylls was expressed on chlorophyll content basis, an increase in both control and treated samples was observed, although this increment was more important in controls (Fig. 3b).

\subsection{Soluble sugars}

Immediately after treatments, the content of total and reducing soluble sugars increased approximately $35-40 \%$ (Fig. 4) in heat treated samples. During storage at $20^{\circ} \mathrm{C}$, the level of both total and reducing sugars increased after three days and then decreased after five days in controls. Differently, a continuous decrement of sugar content was observed in treated samples. Nevertheless, the content of both total and reducing soluble sugars maintained higher in treated samples when compared with the controls after five days.

\subsection{Total and soluble protein content}

Total protein content diminished during storage in both control and treated heads (Fig. 5a), with no significant difference between samples.

Content of soluble proteins represented approximately $40 \%$ of the total protein. Treated samples showed an increment of about $50 \%$ immediately after heating. During storage, the level of soluble proteins diminished continuously in control heads, while treated samples had a decrement during the first three days and then

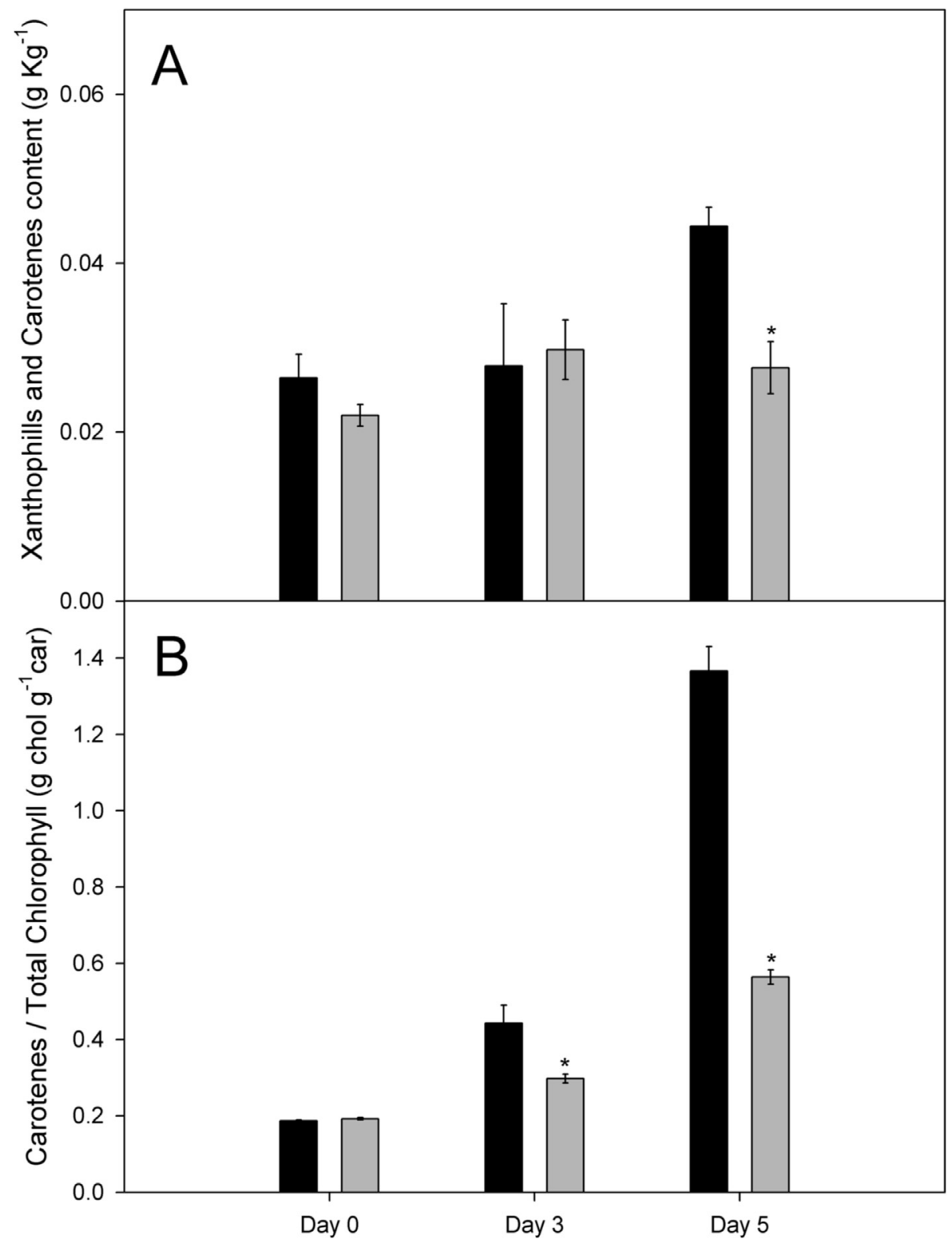

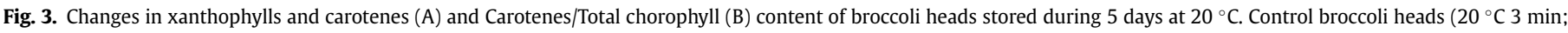

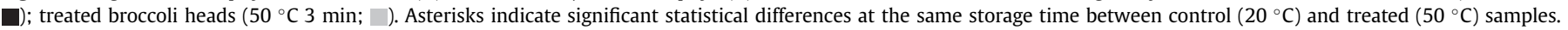




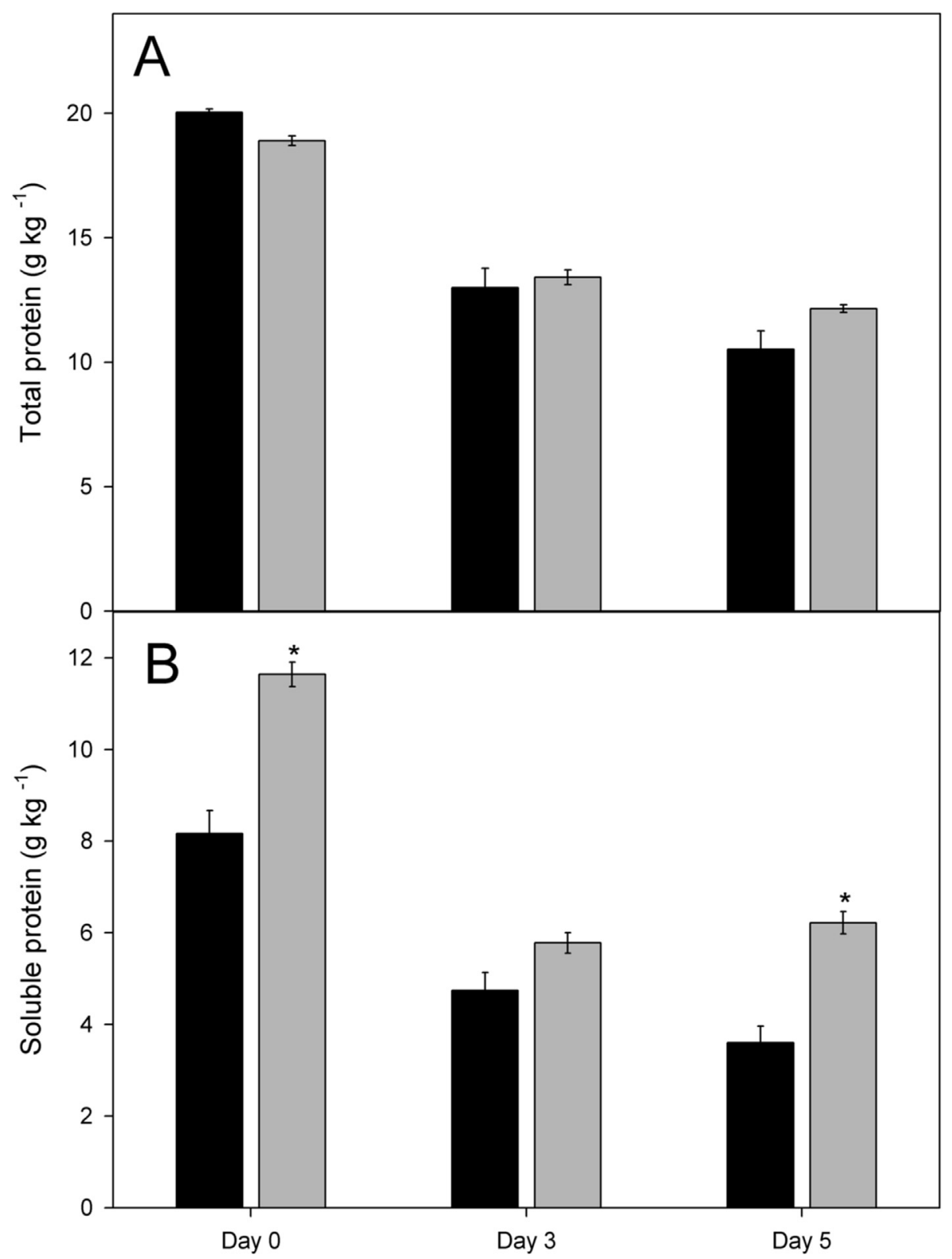

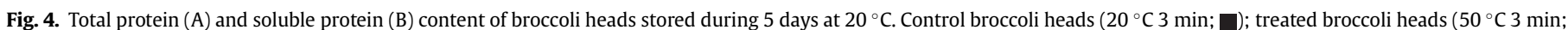
). Asterisks indicate significant statistical differences at the same storage time between control $\left(20^{\circ} \mathrm{C}\right)$ and treated $\left(50{ }^{\circ} \mathrm{C}\right)$ samples.

remained constant until the end of the storage. As a consequence, the content of soluble proteins detected in treated samples was higher than that in controls after five days (Fig. 5b).

\subsection{Phenolic compounds content}

In control samples, the level of phenolics compounds decreased after three days and then increased at the end of storage (Fig. 6). Heating caused an increment in the level of phenolics at the beginning of the experiment. Then, the content of these compounds decreased during storage reaching lower values than controls.

\section{Discussion}

As previously mentioned, moderate heat treatments can delay postharvest senescence of different horticultural vegetables. In this work, we implement a new method to carry out the treatment by heating only $5 \mathrm{~cm}$ above the stem cutting area.

The reason for such treatment is the location of the main area of ethylene metabolism. The genes coding for enzymes responsible for the biosynthesis of this hormone are particularly expressed in the cutting zone (Kato et al., 2002). Having in mind that heat treatment could cause a temporary inhibition of the expression of these genes-, we decided to perform the treatment only in the area of higher gene expression. A similar treatment, performed only in cut stem of lily flowers, delayed leaf senescence and the onset of yellowing by 3-4 days (Woolf et al., 2012). The treatment maintained higher chlorophyll content and better values of chlorophyll fluorescence indicating lower chlorophyll degradation in lily leaves.

We performed several combinations of time/temperature and evaluated changes in superficial colour of heads during postharvest storage. The optimum combinations were $50{ }^{\circ} \mathrm{C}$ during 3 and $5 \mathrm{~min}$, which produced the longer maintenance of green colour. Lower 


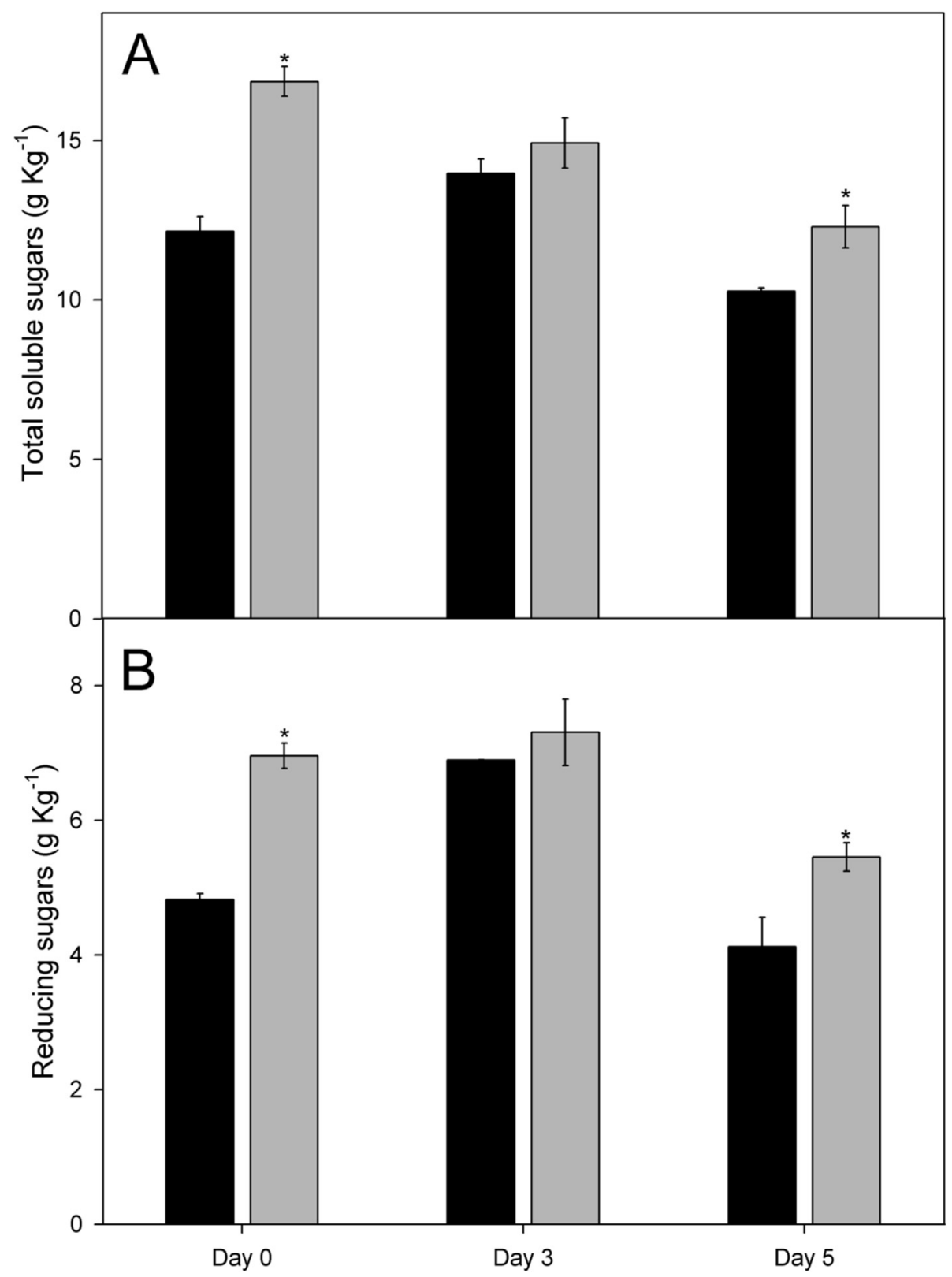

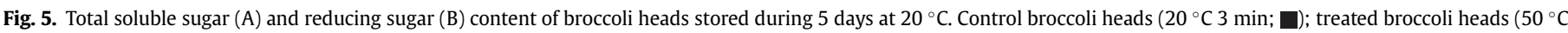
$3 \mathrm{~min} ; \quad)$. Asterisks indicate significant statistical differences at the same storage time between control $\left(20^{\circ} \mathrm{C}\right)$ and treated $\left(50{ }^{\circ} \mathrm{C}\right)$ samples.

temperatures maintained the green colour during a longer period of time than controls but during a shorter period of time than the optimum treatment. Higher temperatures did not enhance the efficiency of treatment. Thus, we chose the treatment during $3 \mathrm{~min}$ at $50{ }^{\circ} \mathrm{C}$ due to lower time exposure.

It has been described that membranes suffer a disruption during senescence (Lim, Kim, \& Nam, 2007) which in turn can enhance water loss. In the present work, the selected treatment caused a delay in senescence and a consequent reduction in weight loss during storage. Treated samples also showed a delay in the degradation of chlorophylls at least three days after treatment, similar to that described in other cases of heat treatments performed in broccoli (Costa et al., 2005). The case of xanthophylls and carotenes is peculiar, since the content of these components usually decreases during senescence (Biswal, 1995). However, broccoli is a particular tissue as it is an inflorescence and carotenes and xanthophylls accumulate in petals during flower development. Heat treatment can delay this process and the consequent accumulation of these pigments.

Apart from chlorophyll degradation, important compositional changes occur during the senescence of broccoli. A decrement in the content of proteins, sugars and fatty acid were previously described (Page et al., 2001; Pogson \& Morris, 1997).

Protein catabolism in senescent tissues involves the disruption of the membranes, the release and solubilization of the anchored proteins and the subsequent degradation of soluble proteins (Gregersen, Holm, \& Krupinska, 2008). The performed treatment did not affect the changes in the amount of total proteins but it did affect the levels of soluble proteins. Initially, the treated samples showed an increase of soluble proteins, probably due to a slight 


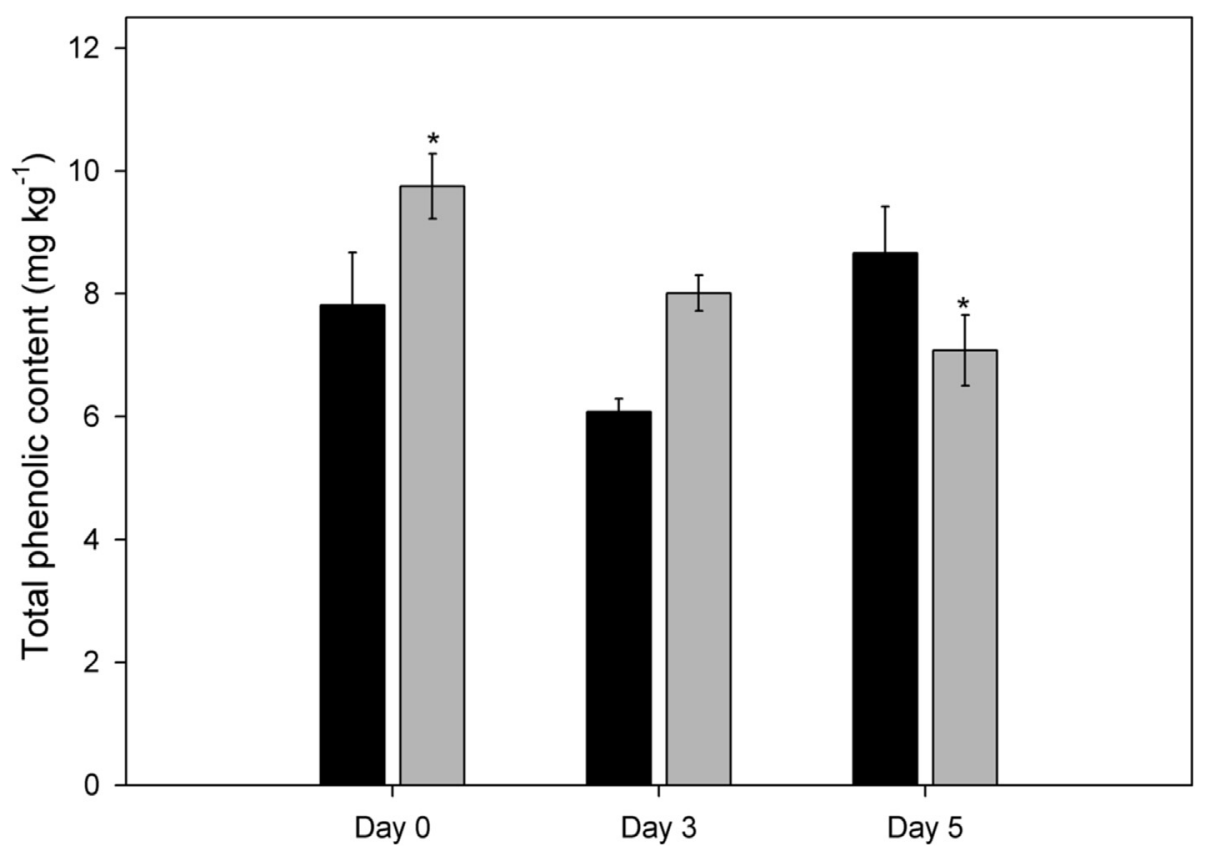

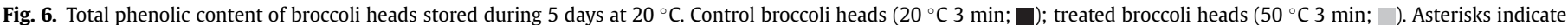
significant statistical differences at the same storage time between control $\left(20^{\circ} \mathrm{C}\right)$ and treated $\left(50{ }^{\circ} \mathrm{C}\right)$ samples.

increase in temperature caused by the treatment, which enhanced the solubilization of proteins. However, during storage, soluble protein degradation was delayed in the treated samples as it was described in broccoli that had other type of heat treatment (Costa et al., 2005).

During senescence of green tissues, starch is degraded while single sugars are translocated to other tissues or utilized as energy substrates. In our case, the increment of soluble (total and reducing) sugars detected by the third day in control samples could have been due to starch degradation (Büchert et al., 2011; Finger, Endres, Mosquim, \& Puiatti, 1999); a fact that could compensate the consumption of single sugars. Once starch is completely degraded, no single sugars are incorporated and its content starts decreasing due to their use as energy substrate. In treated samples, it was detected a momentary increase in soluble sugars similar to the one previously described by Costa et al. (2005). This fact could probably be due to increased starch degradation by the slight increment in temperature of treated samples. However, as in the case of soluble proteins, sugar content was higher in treated samples as usually occurs in heat treatments (Costa et al., 2005).

Both an increment and a decrement in the content of phenolics were reported during postharvest senescence of broccoli (Costa et al., 2005; Starzyńska, Leja, \& Mareczek, 2003). In our case, we detect a slight decrement in control samples after three days and an increment afterwards. As in the case of proteins and sugars, an increased level of phenolics was detected in treated heads immediately after heating. If head temperature increased after treatment, then the activity of enzymes associated with phenolic biosynthesis could also increase. An increment in phenylalanine ammonia-lyase was detected in strawberries immediately after a treatment at $42{ }^{\circ} \mathrm{C}$ for 3 h (Civello, Martínez, Chaves, Añon, \& Añón, 1997) and in mandarins fruit exposed at $37^{\circ} \mathrm{C}$ for $4 \mathrm{~h}$ (Sanchez-Ballesta, Zacarias, Granell, \& Lafuente, 2000). However, at the end of storage (5 days) a lower accumulation of phenols was detected in treated samples. Taking into account that the performed heat treatment caused a delay in the occurrence of senescence, it could also have caused a delay in the accumulation of phenols.

\section{Conclusions}

Application of heat treatments causes a temporary inhibition of senescence during postharvest storage of broccoli (Costa et al., 2005; Tian et al., 1996). In this work, we performed an easier treatment for delaying broccoli senescence by only heating the base of the stem; and we obtained similar results to those previously described by Costa et al. (2005) in relation to this delay during storage.

\section{Acknowledgements}

This work was based on funding from CONICET (Argentina) PIP 00727.

\section{References}

Aiamla-or, S., Kaewsuksaeng, S., Shigyo, M., \& Yamauchi, N. (2010). Impact of UV-B irradiation on chlorophyll degradation and chlorophyll-degrading enzyme activities in stored broccoli (Brassica oleracea L. Italica Group) florets. Food Chemistry, 120(3), 645-651.

Biswal, B. (1995). Carotenoid catabolism during leaf senescence and its control by light Journal of Photochemistry and Photobiology, B: Biology, 30(1), 3-13.

Bradford, M. M. (1976). A rapid and sensitive method for the quantitation of microgram quantities of protein utilizing the principle of protein-dye binding. Analytical Biochemistry, 72(1-2), 248-254.

Büchert, A. M., Civello, P. M., \& Martínez, G. A. (2011). Effect of hot air, UV-C, white light and modified atmosphere treatments on expression of chlorophyll degrading genes in postharvest broccoli (Brassica oleracea L.) florets. Scientia Horticulturae, 127(3), 214-219.

Civello, P. M., Martínez, G. A., Chaves, A. R., Añon, M. C., \& Añón, M. C. (1997). Heat treatments delay ripening and postharvest decay of strawberry fruit. Journal of Agricultural and Food Chemistry, 45(12), 4589-4594.

Costa, M. L., Civello, P. M., Chaves, A. R. \& Martínez, G. A. (2005). Effect of hot air treatments on senescence and quality parameters of harvested broccoli (Brassica oleracea L var Italica) heads. Journal of the Science of Food and Agriculture, 85(7), 1154-1160.

Costa, L., Vicente, A. R., Civello, P. M., Chaves, A. R., \& Martínez, G. A. (2006). UV-C treatment delays postharvest senescence in broccoli florets. Postharvest Biology and Technology, 39(2), 204-210.

Eason, J. R., Patel, D., Ryan, D., Page, B., Hedderley, D., Watson, L., et al. (2007). Controlled atmosphere treatment of broccoli after harvest delays senescence and induces the expression of novel BoCAR genes. Plant Physiology and 
Biochemistry, 45(6-7), 445-456.

Fernández-León, M. F. Fernández-León, A. M. Lozano, M., Ayuso, M. C. \& GonzálezGómez, D. (2013). Altered commercial controlled atmosphere storage conditions for "Parhenon" broccoli plants (Brassica oleracea L. Var. italica). Influence on the outer quality parameters and on the health-promoting compounds. LWT - Food Science and Technology, 50(2), 665-672.

Finger, F. L., Endres, L., Mosquim, P. R., \& Puiatti, M. (1999). Physiological changes during postharvest senescence of broccoli. Pesquisa Agropecuaria Brasileira, 34(9), 1565-1569.

Funamoto, Y., Yamauchi, N., Shigenaga, T., \& Shigyo, M. (2002). Effects of heat treatment on chlorophyll degrading enzymes in stored broccoli (Brassica oleracea L.). Postharvest Biology and Technology, 24, 163-170.

Gapper, N. E., Coupe, S. A., McKenzie, M. J., Scott, R. W., Christey, M. C., Lill, R. E., ... Jameson, P. E. (2005). Senescence-associated down-regulation of 1aminocyclopropane-1-carboxylate (ACC) oxidase delays harvest-induced senescence in broccoli. Functional Plant Biology, 32(10), 891-901.

Gillies, S. L., \& Toivonen, P. M. (1995). Cooling method influences the postharvest quality of broccoli. HortScience, 30(2), 313-315.

Gómez-Lobato, M. E., Hasperué, J. H., Civello, P. M., Chaves, A. R., \& Martínez, G. A (2012). Effect of 1-MCP on the expression of chlorophyll degrading genes during senescence of broccoli (Brassica oleracea L.). Scientia Horticulturae, 144, 208-211.

Gong, Y., \& Mattheis, J. P. (2003). Effect of ethylene and 1-methylcyclopropene on chlorophyll catabolism of broccoli florets. Plant Growth Regulation, 40(1), $33-38$.

Gregersen, P. L., Holm, P. B., \& Krupinska, K. (2008). Leaf senescence and nutrient remobilisation in barley and wheat. Plant Biology, 10(SUPPL. 1), 37-49.

Jia, C. G., Xu, C. J., Wei, J., Yuan, J., Yuan, G. F., Wang, B. L., et al. (2009). Effect of modified atmosphere packaging on visual quality and glucosinolates of broccoli florets. Food Chemistry, 114(1), 28-37.

Kato, M., Kamo, T., Wang, R., Nishikawa, F., Hyodo, H., Ikoma, Y., ... Yano, M. (2002). Wound-induced ethylene synthesis in stem tissue of harvested broccoli and its effect on senescence and ethylene synthesis in broccoli florets. Postharvest Biology and Technology, 24(1), 69-78.

King, G. A., \& Morris, S. C. (1994). Early compositional changes during postharvest senescence of broccoli. Journal of the American Society for Horticultural Science, 119(5), 1000-1005.

Lichtenthaler, H. K. (1987). [34] Chlorophylls and carotenoids: Pigments of photosynthetic biomembranes. Methods in Enzymology, 148(C), 350-382.

Lim, P. O., Kim, H. J., \& Nam, H. G. (2007). Leaf senescence. Anual Review of Plant Biology, 115-136.

Lowry, O. H., Rosebrough, N. J., Lewis Farr, A., \& Randall, R. J. (1951). The folin by oliver. Readings, 193(1), 265-275.

Lurie, S., Jemric, T., Weksler, A., Akiva, R. \& Gazit, Y. (2004). Heat treatment of "Oroblanco" citrus fruit to control insect infestation. Postharvest Biology and Technology, 34(3), 321-329.

Lu, J., Vigneault, C., Charles, M. T., \& Raghavan, G. S. V. (2007). Heat treatment application to increase fruit and vegetable quality. Stewart Postharvest Review, 3(3), 1-7.

Martínez, G. A., \& Civello, P. M. (2008). Effect of heat treatments on gene expression and enzyme activities associated to cell wall degradation in strawberry fruit. Postharvest Biology and Technology, 49(1), 38-45.

Ma, G., Zhang, L., Kato, M., Yamawaki, K., Asai, T., Nishikawa, F., et al. (2010). Effect of 1 -methylcyclopropene on the expression of genes for ascorbate metabolism in postharvest broccoli. Postharvest Biology and Technology, 58, 121-128.

Page, T., Griffiths, G., \& Buchanan-Wollaston, V. (2001). Molecular and biochemica characterization of postharvest senescence in broccoli. Plant Physiology, 125(2) $718-727$.

Pogson, B. J., \& Morris, S. C. (1997). Consequences of cool storage of broccoli on physiological and biochemical changes and subsequent senescence at $20{ }^{\circ} \mathrm{C}$ Journal of the American Society for Horticultural Science, 122(4), 553-558.

Porat, R., Pavoncello, D., Peretz. J., Ben-Yehoshua, S., \& Lurie, S. (2000). Effects of various heat treatments on the induction of cold tolerance and on the postharvest qualities of "Star Ruby" grapefruit. Postharvest Biology and Technology, 18(2), 159-165.

Sanchez-Ballesta, M. T., Zacarias, L., Granell, A., \& Lafuente, M. T. (2000). Accumulation of PAL transcript and PAL activity as affected by heat- conditioning and low-temperature storage and its relation to chilling sensitivity in mandarin fruits. Journal of Agricultural and Food Chemistry, 48(7), 2726-2731.

Southgate, D. A. (1977). The definition and analysis of dietary fibre. Nutrition Reviews, 35(3), 31-37.

Starzyńska, A. Leja, M. \& Mareczek, A. (2003). Physiological changes in the antioxidant system of broccoli flower buds senescing during short-term storage, related to temperature and packaging. Plant Science, 165(6), 1387-1395.

Tian, M. S., Woolf, A. B., Bowen, J. H., \& Ferguson, I. B. (1996). Changes in color and chlorophyll fluorescence of broccoli florets following hot water treatment. Journal of the American Society for Horticultural Science, 121(2), 310-313.

Woolf, A. B., Combes, S., Petley, M., Olsson, S. R., Wohlers, M., \& Jackman, R. C. (2012). Hot water treatments reduce leaf yellowing and extend vase life of Asiatic hybrid lilies. Postharvest Biology and Technology, 64(1), 9-18.

Zieslin, N., \& Ben-Zaken, R. (1992). Effects of applied auxin, gibberellin and cytokinin on the activity of peroxidases in the peduncles of rose flowers. Plant Growth Regulation, 11, 53-57. 